\title{
Exploring Effective Skills Needed in International Marketing: A Case Study on Bangladesh
}

\author{
Mohammad Mobarak Hossain ${ }^{1}$, Nazmun Nahar Shanta ${ }^{2}$ \\ ${ }^{I}$ (Research Assistant, Project Development Unit, e.Gen Consultants Limited, Dhaka, Bangladesh) \\ ${ }^{2}$ (Lecturer, BBA, Shaikh Burhanuddin Post Graduate College, Dhaka, Bangladesh)
}

\begin{abstract}
The purpose of this study is to identify skills required for Bangladeshi firms to be successful in international marketing. An extensive literature review has been made to identify an initial list of skills required in international marketing. Academic practitioners from public and private universities of Bangladesh were surveyed to identify the additional skills required and to know the significance of identified skills and later on a list of highest and lowest rated skills set have been developed. Seventy-two skills were identified as essential to win the global market (identified from literature review and surveying academic practitioners). Identified skills are classified into, and analyzed within five categories which is nothing but marketing mix including (1) Planning and Operational skills; (2) Pricing skills; (3) Promotional skills; (4) Product skills; and (5) Distribution skills. Among identified skills, thirteen was rated as low important, thirty-nine was rated as medium and twenty-two was rated as highly significant. As small firms lack in capital and human sources, this study might help them to find the right person with right skills set and help them to arrange training for the employees. When offering international marketing training programs, organization will be able to identify which skills should be the issue that need to give priority. Business graduates will be able understand which skills set will make them better candidate for the employer. It will help academic practitioner to build up a strong course curriculum. Further studies can be conducted to identify the degree to which these skills are present in employees of Bangladeshi exporting companies and finding out highest and lowest possession of skills among employees, and to identify the gap between the skills these employees have and the skills they need to perform their job.
\end{abstract}

Keywords: Globalization, Marketing, International Marketing, Marketing skills, Marketing Mix.

\section{Introduction}

To gain control on the land of others, to identify better way of living and to identify new regions to make business are the few reasons for which earlier people used to travel around the world. Earlier it was not termed as globalization. The origin of this word is found in Roman, Greek, Egyptian, and Babylonian Empires (Wikipedia, 2011). One of the complex phenomenon in this current world is the globalization which varies in terms of extent and its implications (Johnson and Turner, 2003). Definition of globalization is a matter of debate. Different disciplines define globalization differently. Everyone tries to represent their own perspective. Economics focused on the transfer of goods and services around the world. The political science scholars focus on the role of UNO, WTO, GATT, and similar institutions activities. According to the anthropologist, globalization refers to the interconnectivity among different cultures (Eurostat, 2007). Interconnected activities of Political, Economic, Social, and Technological are known as globalization (Steger, 2009).

The world has changes into a smaller place due to this globalization which further forces to fall the protectionist barriers from national markets (Palmer, 2002). Free movement of capital has been taken place with the fall of protectionist barriers which further paved the way for firms to set up several facilities around the world. This is expanding everyday exponentially and trade volume expanded 7.5 times till 2004 (Farrell, 2007). International marketing activities surround human life. It is true that global market is more challenging and the success in this market depends on several factors which include understanding cultural differences, being literate globally, understanding international cultural, historical, global markets and global economic, social, and political development (Harris et al, 2004). International marketing activities are much more complex than domestic marketing activities for several different reasons. Some of the reasons are diversity in geographic locations, strategies, differences in environmental issues and problems in collecting information (Sustar, 2006). Without being responsive to the local and global situations it is not possible to survive in the current economy. All the firms must be careful about the strategy requirement in the current economy if it wants to survive in the competition (Nemes, 2005).

As international marketing skills are the essential part of business success it is necessary to run a deep research on international marketing skills identification. Though others skills are necessary to be successful in international arena but still international marketing skills remain the priority to be successful in international affairs. A research showed that international marketing skills are the most problematic areas (Busche, 1990). 
Academicians can design international marketing course curriculum by running research into the internationalization of business curriculum. But there are lack of research works. Few research has been taken in the developed world but that is also not much detailed (Gibbs et al., 1995). The study of knowledge construction should continue to explore ways of international marketing. Having international marketing skills will allow employees to accumulate knowledge. More knowledge will help them to adjust technological changes for improving their prospects or to explore the potential markets (Wills, 1993). All the above research identified skills required to be successful in international marketing. Marketing mix includes product, price, place, and promotion (Borden, 1964). Customer sensitivity was one of the most important marketing mix activities (Berry, 1990) which reflects a shift in the marketing mix. Some of the top international marketing skills demanded by all the employers (Hiam \& Charles, 1992).

In present research work, emphasis has been given in different types of international marketing skills. Personal skills are considered vital by current literature as well. How much a firm can perform in the global market is largely depends on how many skills possessed by its employees related to international marketing (Dahringer and Hans, 1991). International marketing is a system of interacting and interrelated activities which demands multifunctional skills (Albaum et al., 2004). Personnel need to be more responsive to the needs of foreign operations. So, that personnel involved in foreign operations need to have more training on international marketing issues. The business environment is more dynamic than before which demands regular training. Now a day, firms have understood that it needs to involve in international marketing for continuous growth. If they want to be involve in international marketing, they need employees having international marketing skills. This is true that they are certain skills which are required to be successful in international marketing. On the other hand, this is also important to identify the importance of each of the required skills (Cateora and Graham, 2002).

The study results are important in numerous ways. Most vital is that the skills identification which are essential to be effective in international marketing mostly at the time rapidly changing global economy. Second, this research work will identify importance of each of the skill. Third, it will be listing all the highest rated and lowest rated skills in different tables. This research work will help to understand the skills required to be successful in international marketing and will also identify prioritize areas for training. There are many parties in this investigation who will be benefitted from this research. Academician will be able to select course description by matching market demand; Organization will be able to select training module for the personnel development; Students will understand what skills to attract them to the employer and so on to help.

Thus, ranking the identified skills based on importance is the main objective of this research work which will be fulfilled by identifying skills required to be successful in international marketing. In this regard, this research solves the following research question,

I. What are the skills needed to be successful in international marketing arena?

II. What is the importance of each identified skill?

III. What are the highest rated and lowest rated skill sets?

\section{Review of Literature}

Several benefits arose when firms involve in international business. Some of the benefits are increasing of level of employment, industrial development, and increase of foreign exchange reserve of the country whilst also improving the position of the firms by increasing profitability, sales volume and market share as well. Thus, international business brings prosperity for the firms and national economies also but being successful in the international market is not that much easy. To be successful in international marketing, companies require a large extent of knowledgeable and skilled employees. Being a developing country, Bangladeshi firms are largely involved with the international market. Unfortunately, no research exists attempting to identify and rank the practical skill requirements of the Bangladeshi firms. Most of the researches have taken place in the USA and Europe. There are very few studies who have focused on developing countries. Therefore, this study will address the question of "which practical skills are important to be successful in international arena by Bangladeshi companies'.

The world is changing very fast which mark its impact on our daily life. Globalization is all about integration of markets and technology in a way that enables individuals, firms, or nations to reach around the world faster and deeper and cheaper than ever before (Friedman, 2000). Now a day, internationalization has become the corporate requirement. Firms understand that if they don't think of international trade, then they are going to be out of the business (Zodl, 1995). There are two motives for which a firm internationalize. One is proactive and the other is reactive motives (Hollensen 2011). Singer, an American firm, who first successfully internationalizes in Scotland by building factory of machine sewing in 1868. One of the most critical challenges was restricting domestic marketing operations to compete internationally (Denison and McDonald, 1995). Business activities across the national borders are increasing over the last forty-two years. Currently, more than $\$ 1.5$ billion foreign exchange transactions are taking place daily basis. A statistical report shows that approximately $\$ 8.9$ trillion of goods are transacted across the national borders and $\$ 2.10$ trillion of services are 
provided across the borders (Hill, 2009). Local market is not enough for discharging capacity of surplus production. So, that firms look for international market (Cateora, 1993).

At present, global market is more developed than it was before two or three decades (Giddens, 1999). The need for the international operation has been redefined as compulsory cost of doing business. In recent years, international marketing efforts have intensified, and very extensive literature exists about the nature of this field in evolution (Sletten, 1994). In the broadest sense, international marketing is a subset of international business which is defined as the performance of the functions of business across national borders (Keegan \& Mark, 1997). International marketing is an exercise of marketing activity which directs the flow of goods and services to consumers or users in more than one nation for profit (Cateora, 1993). International marketing is not just an international version of marketing. It includes establishing strategies around the world as well as specific strategies for the country including how they will maintain the overall global control and how they will maintain global coordination (Taoka and Don, 1991). On the other hand, many authors have tried to align international marketing with the field of marketing. The only difference that prevail between both is the selling goods and services across the political borders (Albaum et al., 1994). Researches said that the difference seems small but requires difference approach to marketing, solving the marketing problems and developing a policy of commercialization and implementation of marketing programs.

Marketing rules and regulations are not different internationally (Daniel and Lee, 1995). However, different environments in different countries often cause managers to ignore the important variables or misinterpreted information. Basic functions of the national and international market are the same but recognized that the task of international marketing is much more difficult (Ball and McCulloch, 2005). There is a considerable difference exists between the national and international marketing that looks should not be with different marketing concepts, so much as with the environment within which marketing must be implemented (Monye, 1995). He admits that not all scholars accept that international marketing different from basic marketing. Research on the phenomenon of international marketing had substantially lagged the national marketing phenomena. Clearly progress, however, has made in this direction since the ability to give education in the international dimension of the specific functional areas has been greatly extended (Albaum and Peterson, 1984).

The dynamic nature of market demands managers having different skills (Bartlett and Ghoshal, 1992). Proper training is required for the purposes of achieving the skills in the world of competition; many organizations have a priority in the training of employees and introduced the need for skills along with the development of products and services. A firm needs to update its workforce both in terms of skills essential for the performance of their work and their career if it wants to engage in cross border trade (Nemes, 2005). This seems to give more support for enhancing emphasis on education and training in a specific field. This need for training is required because the control of the international marketing elements will be crucial in coming decades (Czinkota et al., 1995). There is a positive relationship between the international marketing skills and performance of the firms in the international market (Piercy et al., 1998). International marketing skills are very much important component for the success in international business (Burca et al., 2004).

Many literature reviews were done in relation to the determination of what skills are necessary for success in international marketing. The literature gives various organizational frameworks that focused in general elements of international marketing: the decision regarding five areas for international marketing presented by Keegan and Mar (1997); four dimensions of global marketing according to Quelch and Edward (1986); twenty-six elements are drawn by Albaum et al., (1994); while fourteen uses of international marketing were illustrated by Cateora (1993). Skills required to be successful in international marketing are distributed under four categories in most of the studies which are also known as marketing mix (Branch, 2001). International marketing manager faces more complex situations than domestic marketing manager faces. Marketing mix are more complex in international marketing (Wall and Rees, 2004). However, observed literature did not provide any framework which focused on skills. This identifies five different skills by using traditional four Ps of marketing and added planning as skill categories. Five skills are (1) Planning and Operational skills; (2) Pricing skills; (3) Product skills; (4) Distribution skills; (5) Promotion skills.

For the development of skills required for success in international marketing, consensual validation has been used as a tool. This is the process through which independent variable has been identified based on the appearance in scholarly literature. Twenty-four skills have been developed through consensual validation and validation by thirty-five authors. The available sources and scholarly literature have validated each skill. All the skills have been presented in table 1 with its skills categories. 
Table 1: Category of skills required for effective International marketing and the respective skills identified from the literature:

\begin{tabular}{|l|l|}
\hline Skills Category & Skills \\
\hline Planning Skills & Write down an international marketing plan. \\
& Judge implications of legal environment of foreign market. \\
& Acclimatize to foreign business practices and protocol. \\
& Assess the effectiveness of activities of international marketing. \\
& Conduct a competitive analysis in global level. \\
& Communicate undoubtedly with others when English is not their first language. \\
& Segment international markets for business. \\
& Design a management information system. \\
& Examine foreign market shares. \\
& Investigate human resources tasks and design appropriate organizational structure. \\
& Review International marketing training needs. \\
& Speak at least in a foreign language. \\
& Examine government regulations regarding export and import. \\
& Develop insights concerning foreign individual and group buying behaviors. \\
\hline Pricing Skills & Forecast revenue and bottom line associated to international markets. \\
& Apply correct trade financing programs. \\
& Set overall pricing for international markets successfully. \\
\hline Product Skills & Assess sustainability of your products to foreign markets. \\
& Build up international branding strategies. \\
\hline Distribution Skills & Employ suitable foreign market entry alternatives. \\
& Pick, recruit, compensate and supervise an international sales force. \\
& Make balance between distribution efficiency and distribution effectiveness. \\
\hline Promotional Skills & Choose suitable promotional mix. \\
& Choose suitable international advertising agency. \\
\hline
\end{tabular}

The above literature clearly shows that the field of international marketing has been covered widely in the literature. However, yet disparate, and sometimes confliction arises, have sprung up scientific opinions in relation to the field. Different studies have found that strong needs must exist for training in the field of international marketing. Evidence was also presented which noted to the need to identify the specific skills needed for success in international marketing.

\subsection{Introduction}

\section{Methodology}

The main purpose of this study was to find out highest and lowest rated skills required to be successful in international marketing. For fulfilling the main purpose two other objectives had been set up as (1) identify the skills required to be effective in international marketing; (2) identify the level of importance of each of these skills. For objective 1, researchers studied available literature to find the skills required in international marketing and survey method used among academic practitioners for any inclusion of skills required for international marketing success. For objective 2, researchers surveyed academic practitioners to identify the importance of identified skills in terms of degree and the main objective has been generated from the objective one and objective two.

As this research, does not intend to develop or defend any hypothesis, descriptive research design has been used. In descriptive research, facts, and characteristics of the area of interest are presented systematically (Isaac and William, 1995). For data collection purpose, conventional survey method has been used. A questionnaire has been developed and sent the same to the respondents. Later on, telephonic communication has been made to ensure high response rate (Linstone and Turoff, 2002).

As this research intended to identify the additional skills required in international marketing, qualitative method has been used. Though it is a qualitative research, researchers will use a mix method of data collection. Qualitative research involves dealing with a great deal of information without collection and analysis of numbers or statistical procedures (Kara, 2012).

\subsection{Population and Sample}

The target population of this research was academicians from public and private universities in Bangladesh. The sampling was non-probability expert sample. The following criteria has been set up selecting respondents: (1) having at least two years' experience in teaching international marketing at graduate level; (2) having at least one scholarly article in the field of international marketing. The size of the sample was thirty (30) academic practitioners.

\subsection{Instrumentation}

Survey has been conducted two times among the academicians with two different questionnaires. In first questionnaire, a list of skills identified through literature study has been presented and respondents were 
asked to add if they think any additional skill need to be mentioned in a particular category. The literature produced a list of twenty-four skills that are required to be successful in international marketing arena. The first survey questionnaire contained that list.

A new list of skills has been developed by considering all the additional skills suggested by the respondents which has been forwarded to the respondents. Respondents were asked to rate the importance of the each identified skill for effective international marketing. Rating were based on eight point Likert scale, whereby a rating of one represented "unimportant" and a rating of eight presented "very important". Even Likert scale has been used for avoiding option of remaining neutrality (Change, 1994).

\subsection{Data Collection Procedures}

Two rounds of survey have been completed among the respondents. A list of skills has generated through extensive literature review which forms the initial skills list. These skills were presented in five broad categories. In first survey, respondents were asked to provide additional skills with identified one. In second survey, they were asked to provide rating for each of the identified skill based on significance in international marketing. Researchers have spent considerable time and effort for selecting a proper methodology for this research. The later part of this paper will present the findings and data analysis.

\section{Research Results}

Two main objectives of this research work were identifying the skills required to be effective in international marketing and identifying the level of importance of each of these skills. After completing these two objectives, a list for highest and lowest rated skills has been presented in the later part. For identifying which skills are needed for success in international marketing data were gathered from sample participants. First, an extensive literature review has been made for generating the initial list of skills, then, was extended with skills suggested by the participants. In another survey, respondents have provided the degree of importance for each of the skill. Rating were collected across eight point Likert scale.

\subsection{Required Skills with importance}

An initial list of twenty-four skills has been generated through an extensive literature review. These skills have been organized in five different categories. Categories are (1) Planning and Operational skills; (2) Pricing skills; (3) Product skills; (4) Distribution skills; (5) Promotion skills.

Through first survey, additional skill list has been generated. The survey resulted in total of seventytwo skills among in five broad categories. Initially, planning skills were fourteen and now it is nineteen while the list of pricing skills was expanded from three skills to fourteen. The number of distribution skills increased from three to thirteen and product skills increased from two to thirteen and promotion skills went from two to thirteen.

Through second survey, respondents have provided rating based on importance of each of the skill for effective international marketing. Ratings were collected across an eight-point Likert scale where $1=$ "not important," and $8=$ "very important." The results are presented in table 2, with importance ratings rounded to the nearest whole number.

Table 2: Rating of International Marketing Skills

\begin{tabular}{|c|c|c|c|c|c|c|c|}
\hline SL & Skills & Q1 & Q3 & IQR & Mean & Max & Min \\
\hline & Planning Skills & & & & & & \\
\hline 1 & Write down an international marketing plan & 6.75 & 7.25 & 0.5 & 7 & 8 & 6 \\
\hline 2 & Judge implications of legal environment of foreign market & 6 & 8 & 2 & 7 & 8 & 6 \\
\hline 3 & Acclimatize to foreign business practices and protocol. & 7 & 8 & 1 & 7.5 & 8 & 7 \\
\hline 4 & Assess the effectiveness of activities of international marketing & 6 & 8 & 2 & 7 & 8 & 6 \\
\hline 5 & Conduct a competitive analysis in global level & 6.75 & 7.25 & 0.5 & 7 & 8 & 6 \\
\hline 6 & $\begin{array}{l}\text { Communicate undoubtedly with others when English is not their first } \\
\text { language }\end{array}$ & 7 & 8 & 1 & 7.5 & 8 & 7 \\
\hline 7 & Segment international markets for business & 6 & 6 & 0 & 6 & 7 & 5 \\
\hline 8 & Design a management information system & 7 & 8 & 1 & 7.5 & 8 & 6 \\
\hline 9 & Examine foreign market shares & 7 & 8 & 1 & 7.5 & 8 & 7 \\
\hline 10 & Investigate human resource tasks and design appropriate structure & 4 & 6 & 2 & 5 & 6 & 4 \\
\hline 11 & Review international marketing training needs & 4 & 6 & 2 & 5 & 6 & 4 \\
\hline 12 & Speak at least in a foreign language & 4.75 & 5.25 & 0.5 & 5 & 6 & 4 \\
\hline 13 & Examine government regulations regarding export and import & 7 & 7.25 & 0.25 & 7 & 8 & 5 \\
\hline 14 & $\begin{array}{l}\text { Develop insights concerning foreign individual and group buying } \\
\text { behaviors. }\end{array}$ & 6.75 & 7.25 & 0.5 & 7 & 8 & 6 \\
\hline 15 & Profit repatriation plans development & 6.75 & 7.25 & 0.5 & 7 & 8 & 6 \\
\hline 16 & $\begin{array}{l}\text { Evaluate the effectives and efficiency of your international marketing } \\
\text { activities }\end{array}$ & 6 & 8 & 2 & 7 & 8 & 6 \\
\hline 17 & Overseas market visits/ tours planning & 5 & 7 & 2 & 6 & 7 & 5 \\
\hline
\end{tabular}


Exploring Effective Skills Needed in International Marketing: A Case Study on Bangladesh

\begin{tabular}{|c|c|c|c|c|c|c|c|}
\hline 18 & $\begin{array}{l}\text { Examine issues regarding political/economic/historic/cultural trends of a } \\
\text { country }\end{array}$ & 7 & 8 & 1 & 7.5 & 8 & 7 \\
\hline \multirow[t]{2}{*}{19} & Ability to react to market opportunities quicker than competitors & 7 & 8 & 1 & 7.5 & 8 & 7 \\
\hline & Pricing Skills & & & & & & \\
\hline 20 & Forecast revenue and bottom-line associated to international markets & 6 & 8 & 2 & 7 & 8 & 6 \\
\hline 21 & Apply correct trade financing programs & 5 & 7 & 2 & 6 & 7 & 5 \\
\hline 22 & Set overall pricing for international markets successfully & 6.75 & 7.25 & 0.5 & 7 & 8 & 6 \\
\hline 23 & Assessment and selection of international pricing to strategies & 7 & 8 & 1 & 7.5 & 8 & 7 \\
\hline 24 & Identify and adjust for customer service costs. & 6 & 6 & 0 & 6 & 7 & 5 \\
\hline 25 & $\begin{array}{l}\text { International quotations development using a variety of INCOTERMS } \\
\text { and different foreign currencies. }\end{array}$ & 6 & 6 & 0 & 6 & 7 & 5 \\
\hline 26 & Able to differentiate between full cost and incremental cost & 6.75 & 7.25 & 0.5 & 7 & 8 & 6 \\
\hline 27 & $\begin{array}{l}\text { Able to calculate costs associated with overseas customs duties and } \\
\text { regulations. }\end{array}$ & 7 & 7.25 & 0.25 & 7 & 8 & 5 \\
\hline 28 & Able to utilize the most effective transfer pricing practices. & 5 & 7 & 2 & 6 & 7 & 5 \\
\hline 29 & Able to analyze and manage activities of "gray market" & 5 & 7 & 2 & 6 & 7 & 5 \\
\hline 30 & Capable to negotiate effectively in a multicultural setting arena. & 7 & 8 & 1 & 7.5 & 8 & 7 \\
\hline 31 & Able to assess different countries tax incentives areas. & 4 & 6 & 2 & 5 & 6 & 4 \\
\hline 32 & Assessment and selection of suitable international payment methods & 6.75 & 7.25 & 0.5 & 7 & 8 & 6 \\
\hline \multirow[t]{2}{*}{33} & Determine international exchange rate previously. & 7 & 8 & 1 & 7.5 & 8 & 7 \\
\hline & Product Skills & & & & & & \\
\hline 34 & Assess suitability of your products to foreign markets. & 7 & 8 & 1 & 7.5 & 8 & 7 \\
\hline 35 & Build up international branding strategies & 6 & 6 & 0 & 6 & 7 & 5 \\
\hline 36 & Assess appropriateness of product adaptation versus standardization. & 7 & 8 & 1 & 7.5 & 8 & 7 \\
\hline 37 & Able to evaluate local brands and devise international branding strategies & 6 & 6 & 0 & 6 & 7 & 5 \\
\hline 38 & Review various classification numbering systems (e.g. SIC, HTS, SITC). & 6 & 8 & 2 & 7 & 8 & 6 \\
\hline 39 & Evaluate and select product sourcing strategies & 6 & 6 & 0 & 6 & 7 & 5 \\
\hline 40 & $\begin{array}{l}\text { Secure foreign government approvals (Product, safety, environmental } \\
\text { and quality standards) }\end{array}$ & 6.75 & 7.25 & 0.5 & 7 & 8 & 6 \\
\hline 41 & Able to understand and protect intellectual property rights & 6 & 6 & 0 & 6 & 7 & 5 \\
\hline 42 & Identify "what you are selling" & 6 & 8 & 2 & 7 & 8 & 6 \\
\hline 43 & Determine product life cycle strategy of the product in each market. & 7 & 8 & 1 & 7.5 & 8 & 7 \\
\hline 44 & $\begin{array}{l}\text { Develop foreign repaid and service system (warranty, repair, spare parts } \\
\text { policies) }\end{array}$ & 6 & 6 & 0 & 6 & 7 & 5 \\
\hline 45 & Review packaging, packing, and labeling requirements & 6.75 & 7.25 & 0.5 & 7 & 8 & 6 \\
\hline \multirow[t]{2}{*}{46} & $\begin{array}{l}\text { Need to know the product/service safety issues (Some countries specially } \\
\text { developed market concentrate on safety and quality issues). }\end{array}$ & 6 & 8 & 2 & 7 & 8 & 6 \\
\hline & Distribution Skills & & & & & & \\
\hline 47 & Employ suitable foreign market entry alternatives & 7 & 8 & 1 & 7.5 & 8 & 6 \\
\hline 48 & Pick, recruit, compensate, and supervise an international sales force & 7 & 8 & 1 & 7.5 & 8 & 7 \\
\hline 49 & $\begin{array}{l}\text { Make balance between distribution efficiency and distribution } \\
\text { effectiveness }\end{array}$ & 6 & 6 & 0 & 6 & 7 & 5 \\
\hline 50 & $\begin{array}{l}\text { Able to assess and select proper international alternatives (especially } \\
\text { where there are no existing routes) }\end{array}$ & 4 & 6 & 2 & 5 & 6 & 4 \\
\hline 51 & Identify, evaluate, and select foreign distributors/agents/EMC/ETC & 7 & 8 & 1 & 7.5 & 8 & 7 \\
\hline 52 & Able to develop just-in-time/ kanban inventory systems & 4 & 6 & 2 & 5 & 6 & 4 \\
\hline 53 & $\begin{array}{l}\text { Evaluate appropriateness of joint ventures and strategic alliances and } \\
\text { other entry alternatives }\end{array}$ & 4.75 & 5.25 & 0.5 & 5 & 6 & 4 \\
\hline 54 & Able to deal with foreign customs brokers/ clearing agents & 4 & 6 & 2 & 5 & 6 & 4 \\
\hline 55 & Able to obtain export licenses & 6 & 6 & 0 & 6 & 7 & 5 \\
\hline 56 & Assessment and selection of a freight forwarder & 5 & 7 & 2 & 6 & 7 & 5 \\
\hline 57 & Assess environmental factors/ geography affecting physical distribution & 4 & 6 & 2 & 5 & 6 & 4 \\
\hline 58 & $\begin{array}{l}\text { To familiar with degree of commitment or involvement towards } \\
\text { international marketing (whether the intended company wants to } \\
\text { concentrate on only irregular exporting or regular exporting, then the } \\
\text { company can capable to employ appropriate foreign entry strategies). }\end{array}$ & 6 & 6 & 0 & 6 & 7 & 5 \\
\hline \multirow[t]{2}{*}{59} & To be well-informed about geographical distance and proximity. & 3 & 5 & 2 & 4 & 5 & 3 \\
\hline & Promotion Skills & & & & & & \\
\hline 60 & Choose suitable promotional mix & 7 & 8 & 1 & 7.5 & 8 & 7 \\
\hline 61 & Choose suitable international advertising agency & 7 & 8 & 1 & 7.5 & 8 & 7 \\
\hline 62 & Evaluate and select appropriate direct mail to company & 4 & 6 & 2 & 5 & 6 & 4 \\
\hline 63 & Appropriately utilize export promotion programs of different countries & 5 & 7 & 2 & 6 & 7 & 5 \\
\hline 64 & Able to select proper communication channels & 6.75 & 7.25 & 0.5 & 7 & 8 & 6 \\
\hline 65 & Evaluate and select appropriate internet marketing service providers & 7 & 7.25 & 0.25 & 7 & 8 & 5 \\
\hline 66 & Identify and abide by legal issues relative to foreign promotion & 6.75 & 7.25 & 0.5 & 7 & 8 & 6 \\
\hline 67 & Develop promotional/presentation materials/product literature & 7 & 8 & 1 & 7.5 & 8 & 7 \\
\hline 68 & Evaluate and select appropriate public/governmental relations specialist & 4 & 6 & 2 & 5 & 6 & 4 \\
\hline 69 & $\begin{array}{l}\text { Use trade shows (domestic and international) to promote international } \\
\text { trade }\end{array}$ & 7 & 8 & 1 & 7.5 & 8 & 7 \\
\hline 70 & $\begin{array}{l}\text { Explore other promotional alternatives that may be characteristic of given } \\
\text { country. }\end{array}$ & 7 & 8 & 1 & 7.5 & 8 & 7 \\
\hline
\end{tabular}




\begin{tabular}{|c|c|c|c|c|c|c|c|}
\hline 71 & Evaluate and select appropriate telemarketing organization & 3 & 5 & 2 & 4 & 5 & 3 \\
\hline 72 & $\begin{array}{l}\text { Follow standard rules when going to design and select communication } \\
\text { plans as well as channels although hiring agency from overseas can solve } \\
\text { this problem. }\end{array}$ & 6 & 6 & 0 & 6 & 7 & 5 \\
\hline
\end{tabular}

$\mathrm{N}=30$; (1=" Not Important" through 8=" Very Important")

\subsection{Most and least important international marketing skills}

Out of seventy-two skills, twenty skills were rated as highly important. Among twenty highest rated skills six from planning skills, three from pricing skills, three from product skills, three from distribution skills and five from promotion skills. Thirteen skills were rated as lowest important skills. Among which four from promotional skills, one from pricing skills, five from distributions skills and three from planning and operational skills. Table 3 represents the most and least important international marketing skills.

Table 3: Most and least important international marketing skills

\begin{tabular}{|c|c|c|c|}
\hline SL & Rating & Mean & $\begin{array}{l}\text { Skills } \\
\text { Category }\end{array}$ \\
\hline & Highest Rated Skills & & \\
\hline 1 & Acclimatize to foreign business practices and protocol. & 7.5 & P1 \\
\hline 2 & Communicate undoubtedly with others when English is not their first language. & 7.5 & P1 \\
\hline 3 & Design a management information system & 7.5 & $\mathrm{P} 1$ \\
\hline 4 & Examine foreign market shares & 7.5 & P1 \\
\hline 5 & Examine issues regarding political/economic/historic/cultural trends of a country & 7.5 & $\mathrm{P} 1$ \\
\hline 6 & Ability to react to market opportunities quicker than competitors & 7.5 & P1 \\
\hline 7 & Assessment and selection of international pricing to strategies & 7.5 & $\mathrm{P} 2$ \\
\hline 8 & Capable to negotiate effectively in a multicultural setting arena. & 7.5 & $\mathrm{P} 2$ \\
\hline 9 & Determine international exchange rate previously. & 7.5 & $\mathrm{P} 2$ \\
\hline 10 & Assess suitability of your products to foreign markets. & 7.5 & P3 \\
\hline 11 & Assess appropriateness of product adaptation versus standardization. & 7.5 & P3 \\
\hline 12 & Determine product life cycle strategy of the product in each market & 7.5 & P3 \\
\hline 13 & Employ suitable foreign market entry alternatives & 7.5 & $\mathrm{D}$ \\
\hline 14 & Pick, recruit, compensate and supervise an international sales force & 7.5 & $\mathrm{D}$ \\
\hline 15 & Identify, evaluate, and select foreign distributors/agents/EMC/ETC & 7.5 & $\mathrm{D}$ \\
\hline 16 & Choose suitable promotional mix & 7.5 & P4 \\
\hline 17 & Choose suitable international advertising agency & 7.5 & $\mathrm{P} 4$ \\
\hline 18 & Develop promotional/presentation materials/product literature & 7.5 & $\mathrm{P} 4$ \\
\hline 19 & Use trade shows (domestic and international) to promote international trade & 7.5 & P4 \\
\hline 20 & Explore other promotional alternative that may be characteristics of given country & 7.5 & $\mathrm{P} 4$ \\
\hline & Lowest Rated Skills & & \\
\hline 1 & Investigate human resource tasks and design appropriate organizational structure & 5 & P1 \\
\hline 2 & Review international marketing training needs & 5 & P1 \\
\hline 3 & Speak at least in a foreign language & 5 & P1 \\
\hline 4 & Able to assess different countries tax incentives areas. & 5 & $\mathrm{P} 2$ \\
\hline 5 & $\begin{array}{l}\text { Able to asses and select proper international transportation alternatives (especially where there are } \\
\text { no existing routes) }\end{array}$ & 5 & $\mathrm{D}$ \\
\hline 6 & Able to develop just-in-time/ Kanban inventory systems & 5 & $\mathrm{D}$ \\
\hline 7 & Evaluate appropriateness of joint ventures and strategic alliances and other entry alternatives & 5 & $\mathrm{D}$ \\
\hline 8 & Able to deal with foreign customers/ brokers/ clearing agent & 5 & $\mathrm{D}$ \\
\hline 9 & Assess environmental factors/ geography affecting physical distribution & 5 & $\mathrm{D}$ \\
\hline 10 & Evaluate and select appropriate direct mail to company & 5 & P4 \\
\hline 11 & Evaluate and select appropriate public/ governmental relations specialists & 5 & P4 \\
\hline 12 & To be well-informed about geographical distance and proximity. & 4 & $\mathrm{P} 4$ \\
\hline 13 & Evaluate and select appropriate telemarketing organization & 4 & $\mathrm{P} 4$ \\
\hline
\end{tabular}

P1= Planning Skills; P2=Pricing skills; P3=Product Skills; D= Distribution Skills; P4= Promotion Skills Rating $7>$ means Highest Important skills and rating $5<=$ means lowest important skills

\section{Conclusion}

Researchers have identified a list of skills necessary for effective international marketing and have also identified significance of each of the identified skill. Identified skills have been categorized as planning skills, pricing skills, product skills, distribution skills, and promotional skills. Due to the impact of globalization, firms forced to go international market. Whenever it thinks to go international market, it must buildup certain skills among the employees so that it can win the global market. This research identified seventy-two skills which were identified by the academic practitioner of international marketing and among which 20 skills were very important for the survival of the firms in international market arena. 


\section{References}

[1] Albaum, G., Jesper, S., \& Edwin, D., 2004. International marketing and export management. Upper Saddle River, NJ: Financial Times Prentice Hall

[2] Albaum, G., \& Peterson, R. A., 1984. Empirical research in international marketing. Journal of International Business Studies. Vol15. Pp 161-174

[3] Ball, D. A., Wendell, H., \& McCulloch, Jr., 2005. International business: The challenge of global competition. Burr Ridge, IL: McGraw-Hill/Irwin

[4] Bartlett, C. A., \& Ghoshal, S., 1992. What Is a Global Manager? Harvard Business Review. September/October. Pp 131

[5] Berry, D., 1990. Marketing mix for the '90s adds an S and 2 Cs to 4 Ps. Marketing News. Vol- 24. Issue- 26. Pp 10

[6] Borden, N. H., 1964. The concept of the marketing mix. Journal of Advertising Research. Vol- 4. June. Pp 2-7

[7] Brown Jr., J. R., Harold G., \& Willie E. G., 1991. Enhance your firm's marketing performance via a marketing audit. The Practical Accountant. April. Pp 57-60

[8] Branch, A. (2001). Export Practice and Management. London: Thomson Learning.

[9] Busche, D., \& Marly B., 1990. The global challenge: International trade training needs of California businesses. Irvine, CA: Department of Vocational Eucation, Saddleback College.

[10] Burca, D. S., Brown, L., Fletcher, R. (2004). International Marketing: An SME Perspective. Upper Saddle River: Pearson Prentice Hall.

[11] Cateora, P. R., 1993. International marketing. Homewood, IL: Richard D. Irwin.

[12] Cateora, P.R., \& Graham, J. L., 2002. International marketing. New York, NY: McGraw-Hill

[13] Change, L.A. 1194. Psychometric evaluation of 4 point and 6 point Likert type scale in relation to realibility and validity. Applied Physical measurement. 18:205-215.

[14] Czinkota, M.R., Ilkka A.R., \& John J.T., 1995. The global marketing imperative. Lincolnwood, IL: NTC Business Books.

[15] Dahringer, L. D., \& Hans M., 1991. International marketing: A global perspective. Menlo Park, CA: Addison-Wesley Publishing Company.

[16] Daniels, J.D., \& Lee H. R. (1995). International business environments and operations. Menlo Park, CA: Addison-Wesley Publishing Company.

[17] Denison, T., \& McDonald, M., 1995. The role of marketing past, present and future. Journal of Marketing Practice: Applied Marketing Science. Vol-1. Issue-1. Pp 54-76

[18] Giddens, A., 1999. BBC Reith Lectures: Globalization. [Online]. Available at: http://globaledge.msu.edu/ibrd/offside.asp

[19] Gibbs, B., Robert G., \& Jim M., 1995. Learning in the workplace through employee development: Three perspectives. Training and Management Development Methods.

[20] EuroStat. (2007). Euro Indicator, Selected Readings, Focus on: Measuring Globalization. Luxembourg: Eurpoean Commission.

[21] Farrell, R. R. (2007). The Future of Globalization. Retrieved March 26, 2017, from Website of The Real Truth, Magazine: [Online]: Available at: http://www.realtruth.org/articles/070223-001-globalization.html

[22] Harris, P. R., Moran, T. M. \& Moran, S. V., 2004. Managing Cultural Differences. Burlington, MA: Elsevier ButterworthHeinemann.

[23] Hiam, A. \& Charles, D. S., 1992. The portable MBA in marketing. New York: John Wiley and Sons.

[24] Hamilton, L., \& Webster, P. (2009). The International Business Enviroment. New York: Oxford Univeristy Press.

[25] Hill, C. W. (2009). International Business. New York: McGraw-Hill

[26] Hollensen, S. 2011. Global Marketing a Decision Oriented Approach, Pearson Education Limited, 5th Ed, England.

[27] Isaac, S. \& William, B. M., 1995. Handbook in research and evaluation. San Diego, CA: Edits Publishing Company.

[28] Johnson, D., Turner, C. (2003). International Business: Themes and Issues in the Modern Global Economy. London: Routledge Taylor \& Francis Group.

[29] Kwok, C. Y., Jeffrey, A. \& William, R. F. Jr., 1994. A global survey of international business education in the 1990s. Journal of International Business Studies (third quarter). Pp 605-623

[30] Keegan, W. J. \& Mark, C. G., 1997. Principles of global marketing. Upper Saddle River, NJ: Prentice-Hall.

[31] Kara, H. (2012) Research and Evaluation for Busy Practitioners: A Time-Saving Guide. Policy Press.

[32] Linstone, H. A., \& Turoff M., 2002. The Delphi Method: Techniques and Applications. [Online]. Available at: http://www.is.njit.edu/pubs/delphibook/

[33] Monye, S. O., 1995. Research note: International marketing management: A separate academic discipline? An empirical assessment of the need for specialist education and training. International Marketing Review. Vol-12. Issue- 3. Pp 5-14

[34] National Quality Council 2006, Newsletter, issue no. 1. [Online]. Available at: http://www.dest.gov.au/NR/rdonlyres/7CE26613EBAD-470D-A9C0 9B41203E2819/14486/QualityCouncilFocusNewsletterIssue01.pdf

[35] Nemes, A., 2005. Time for a Training Rethink. The Institute of Export: Exporting World (July/August). Vol-15. Issue-3.

[36] Palmer, T. G. (2002). Globalization is great! Washington: Cato's Letter.

[37] Piercy, N.F., A. Kaleka and C.S. Katsikeas, 1998. Sources of competitive advantages in high performing exporting companies. J. World Business, 33(4): 378-93

[38] Quelch, J. A. \& Edward, J. H., 1986. Customizing global marketing. Harvard Business Review (May-June). Pp 35-48.

[39] Steger, M. B. (2009). Globalization: A Very Short Introduction. Hampshire: Oxford Univeristy Press.

[40] Scott, L. K., 1989. Survey of business-industry to determine interest in and need for a certificate in international business. San Diego, CA: San Diego Community College District, Department of Vocational Education and Employment Training.

[41] Sletten, E., 1994. How to succeed in exporting and doing business internationally. New York: John Wiley and Sons.

[42] Taoka, G. M., \& Don, R. B., 1991. International business environments, institutions, and operations. New York: Harper Collins Publishers.

[43] Thomas, F., 2000. The Lexus and the Olive Tree: Understanding Globalization. New York: Anchor Books.

[44] Voght, G. M., \& Ray, S., 1992. Foreign languages and international business. ERIC Digest. ERIC Document.

[45] Wall, S., Rees, B. (2004). International Business. Essex: Pearson Education.

[46] Wills, J. L. (1993). An overview of skill standards systems in selected countries 4. Washington, DC: U.S. Department of Education.

[47] Wikipedia. (2011). Economic indicator. [Online]: Available at http://en.wikipedia.org/wiki/Economic_indicator

[48] Wikipedia. (2011). History of Globalization. [Online] available at: http://en.wikipedia.org/wiki/History_of_globalization

[49] Zodl, J. A., 1995. Export-import. Cincinnati, OH: Betterway Books. 